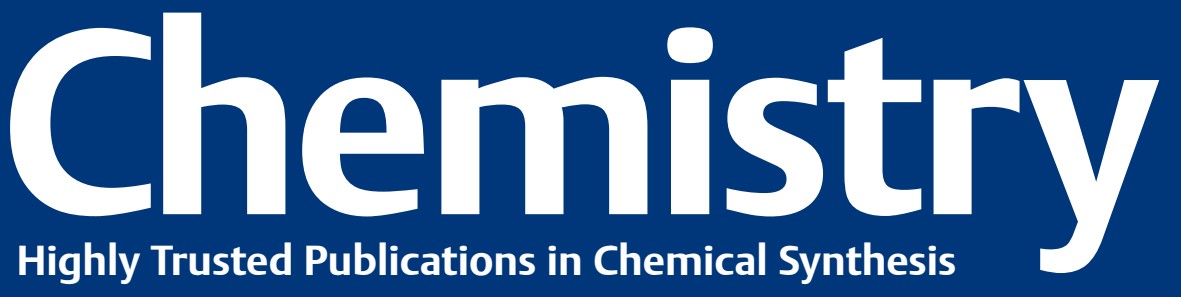

2022

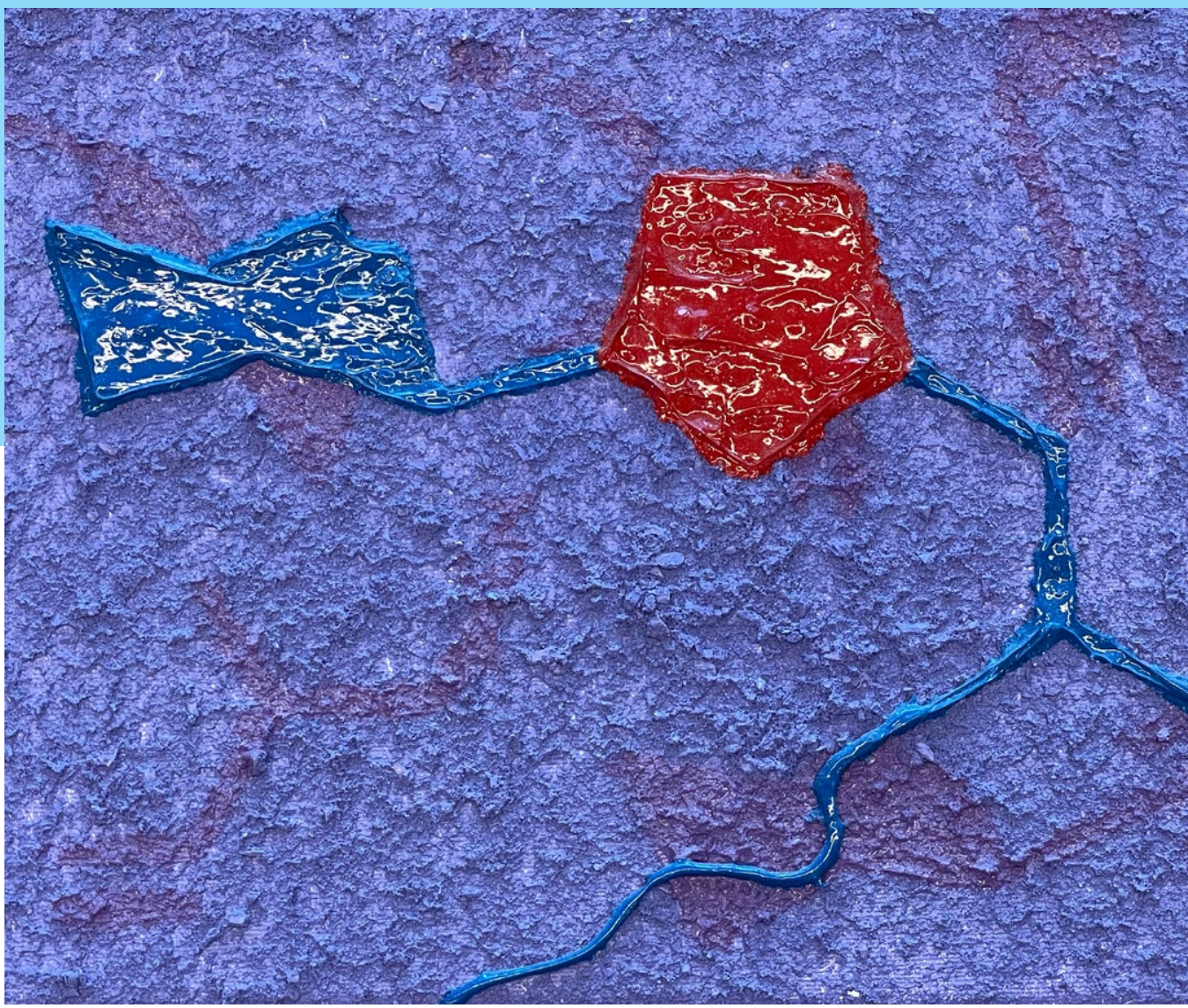

Thieme 


\section{General Information}

Product Overview . . . . . . . . . . . . . . . 4

Prizes \& Awards . . . . . . . . . . . . . . 12

Contact Information . . . . . . . . . . . . . 24

Journals

SynOpen $\ldots \ldots \ldots \ldots \ldots \ldots \ldots \ldots \ldots \ldots$

Organic Materials ................ 7

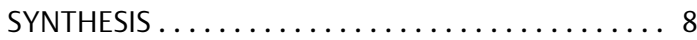

SYNLETT $\ldots \ldots \ldots \ldots \ldots \ldots \ldots \ldots \ldots \ldots \ldots \ldots \ldots \ldots$

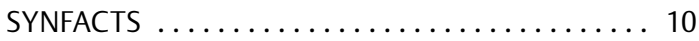

SYNFORM ................... 11

Planta Medica | Drug Research . . . . . . . . . . . 13

Pharmaceutical Fronts .............. 13

\section{Reference Works}

Science of Synthesis . . . . . . . . . . . . . . . . 14

Electronic Edition. . . . . . . . . . . . . 16

Pharmaceutical Substances ... . . . . . . . . . . 18

\section{Encyclopedia}

RÖMPP ...................... 20

\section{Monographs}

Protecting Groups . . . . . . . . . . . . . . 22

Spectroscopic Methods in Organic Chemistry . . . 22 Synthetic Methods of Organometallic and Inorganic

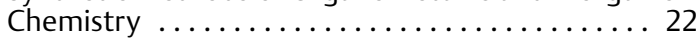

Efficiently Studying Organic Chemistry ....... 23 Spektroskopische Methoden in der organischen

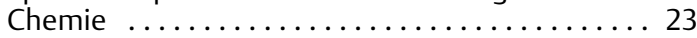

Organische Chemie $\ldots \ldots \ldots \ldots \ldots \ldots \ldots 23$

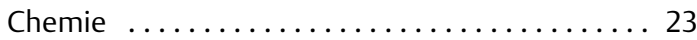
呞
$=$ also available as e-book
( 


\section{Dear Reader,}

What is it about chemistry that fascinates you personally? At Thieme, we like different aspects of chemical synthesis. But one thing connects us: we aim to support and inspire chemists all over the world with their research, work or studies.

When you ask fellow chemists what differentiates Thieme from other publishers, many of them will say that publishing with Thieme feels like being part of a big family. We are happy to hear that and proud to say that everyone here cares personally about our authors and customers. As an independent, family-owned publisher we foster this special Thieme spirit and do our best to provide you with great service every day.
Our small but selected publishing program focuses on the field of chemical synthesis from journals and books to state-of-the-art online products. Our aim is to create the best information tools to support the daily work of the modern synthetic chemist. We hope you continue to trust us when it comes to publishing or using our products.

Now we would like to invite you to explore the world of synthetic organic chemistry at Thieme. Enjoy!

\section{Your Thieme Chemistry Team}

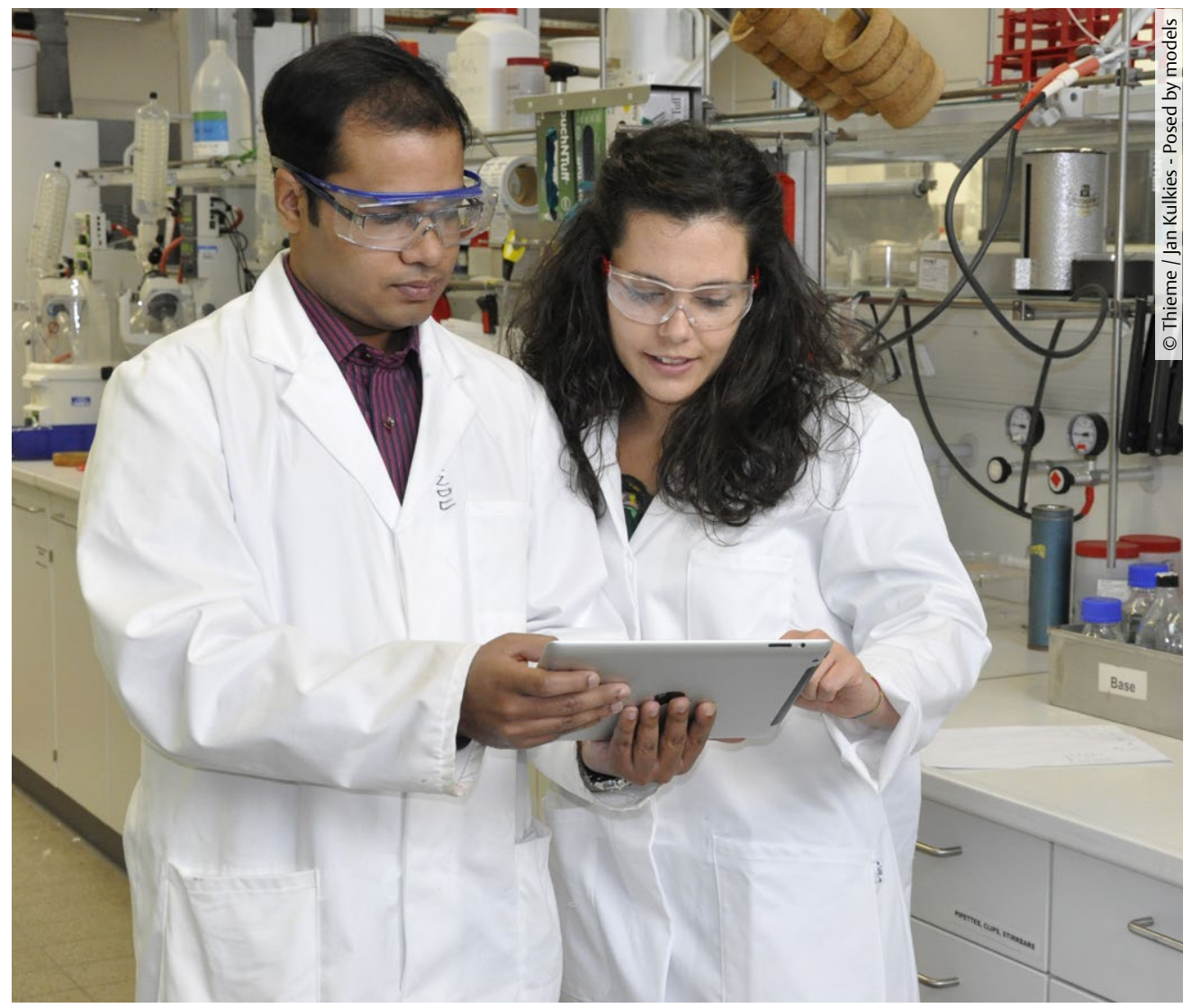




\section{Thieme: Your Trusted Publisher in the Field of Chem}

\section{Journals}

Keep yourself up to date on the latest developments in chemical synthesis with SYNTHESIS, SYNLETT, SYNFACTS and SynOpen and read about current research on materials chemistry in Organic Materials!

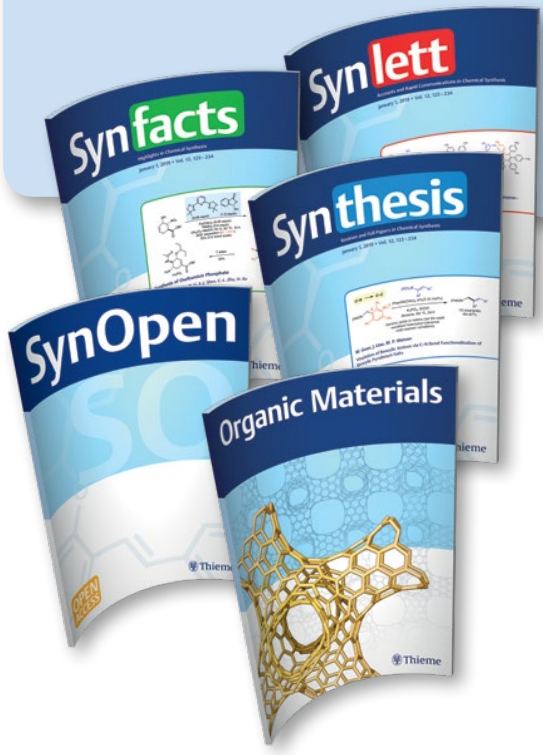

\section{Journals}

\section{RÖMPP}

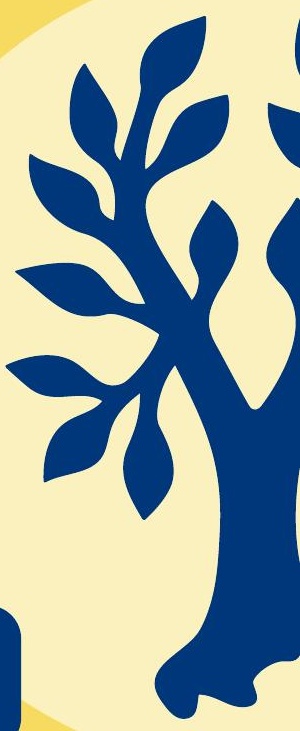

\section{RÖMPP}

Explore RÖMPP, the renowned German language encyclopedia covering chemistry and related topics.
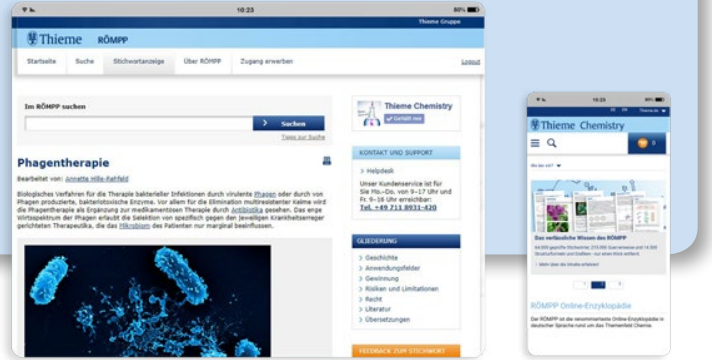
ical Synthesis
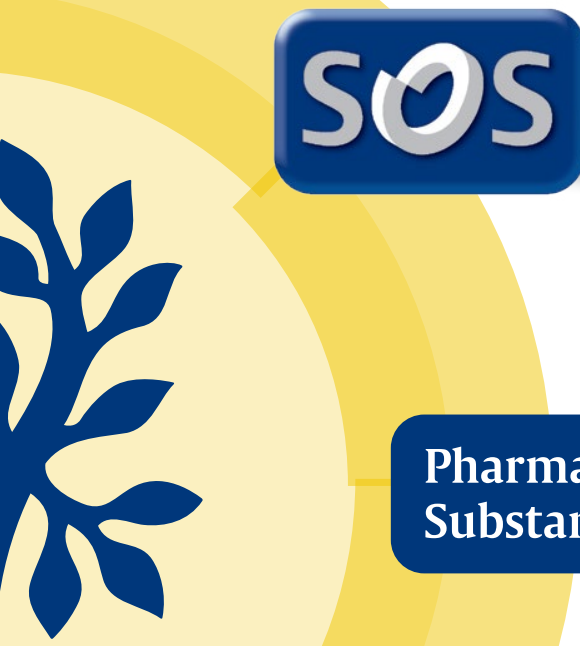

\section{Pharmaceutical} Substances

\section{Monographs}

\section{Monographs}

Complete your literature collection with our chemistry monographs.

\section{Science of Synthesis}

Get more out of your synthesis! This online synthetic methodology tool provides an overview of the most reliable organic transformations at a glance, including full-text reviews.

(4) Thieme science of Synthesis

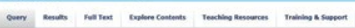

What's New in SOS?

- New content

- New features

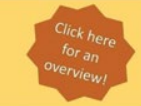

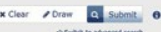

Explore Science of Synthesis
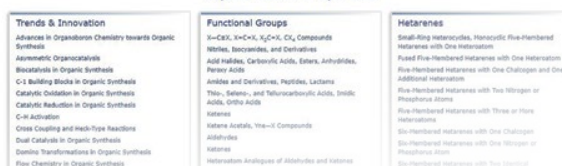

\section{Pharmaceutical Substances}

Find information about industrial syntheses and commercial applications of over 2,700 APIs in this online database!

\section{sery noms sent}

2641 Results

Acemetacin

sent bir mese
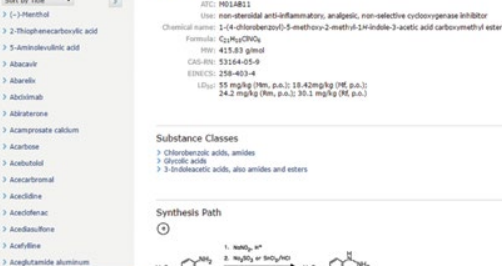

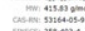

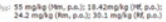

Sustance Classes

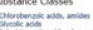

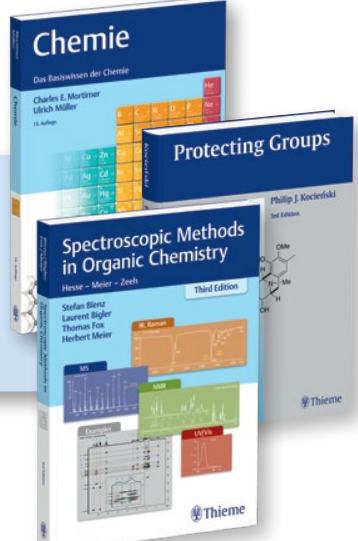

Synthesis pach

$\odot$

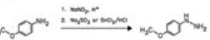

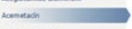

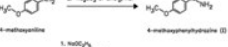

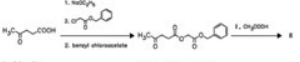




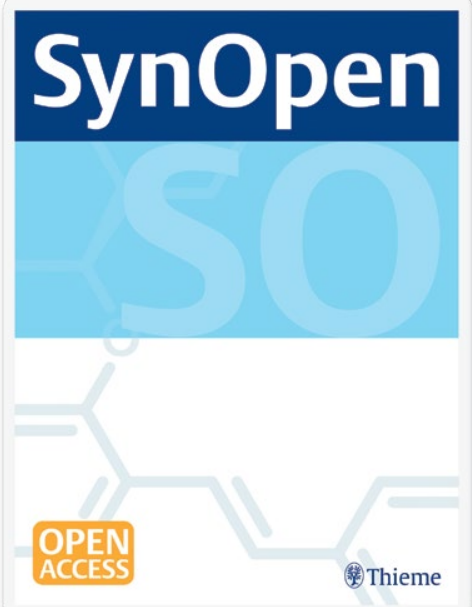

Editor-in-Chief:

Editors:

L. M. Harwood Reading, UK
F. Colobert Strasbourg, France Ch. R. Reddy Hyderabad, India

D. Seidel

Gainesville, USA

Crowd Review Editor: Eduarda M. P. Silva Paredes, Portugal

\section{SynOpen}

\section{Full Papers, Letters and Reviews in Chemical Synthesis}

SynOpen is an international open access journal reporting current research results in chemical synthesis. It covers all fields of scientific endeavor that involve organic synthesis - including catalysis, organometallic, medicinal, biological and photochemistry - but also related disciplines.

- International open access journal

- Reporting original papers, letters, PSPs, reviews, short reviews, graphical reviews and spotlights.

- Publication of chemical primary data

- Select Crowd Review and double-blind review available

www.thieme-chemistry.com/synopen

\section{Discover Thieme Open!}

Thieme Open is the gateway to our open access journal content. It covers both open access journals as well as open access articles published in our subscription journals and provides you with information about publishing open access at Thieme. All open access content at Thieme is freely available online for everyone, increasing the visibility, usage, and impact of your work.

\section{Learn more}

open.thieme.com 


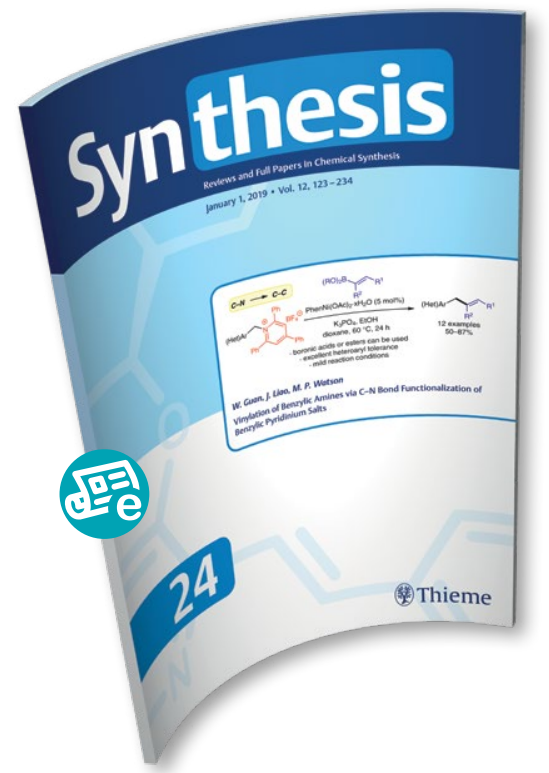

Editor-in-Chief: Editors:

Mark Lautens T. Bach

Toronto, Canada Munich, Germany

H.-L. Bao

Fuzhou, P. R. of China

P. A. Evans

Kingston, Canada

L.-Z. Gong

Hefei, P.R. of China

M. Oestreich

Berlin, Germany

C. S. Schindler

Ann Arbor, USA

H. Yorimitsu

Kyoto, Japan

\section{SYNTHESIS}

\section{Reviews and Full Papers in Chemical Synthesis}

SYNTHESIS is an international full-paper journal devoted to the advancement of chemical synthesis. It covers all fields of organic chemistry involving synthesis, including catalysis, organometallic, medicinal, biological, and photochemistry, but also related disciplines.

- International full-paper journal

- Impact Factor 2020: 3.157

- Publication of chemical primary data

- 24 issues per year

- Dependable research results

- Experimental procedures

www.thieme-chemistry.com/synthesis 


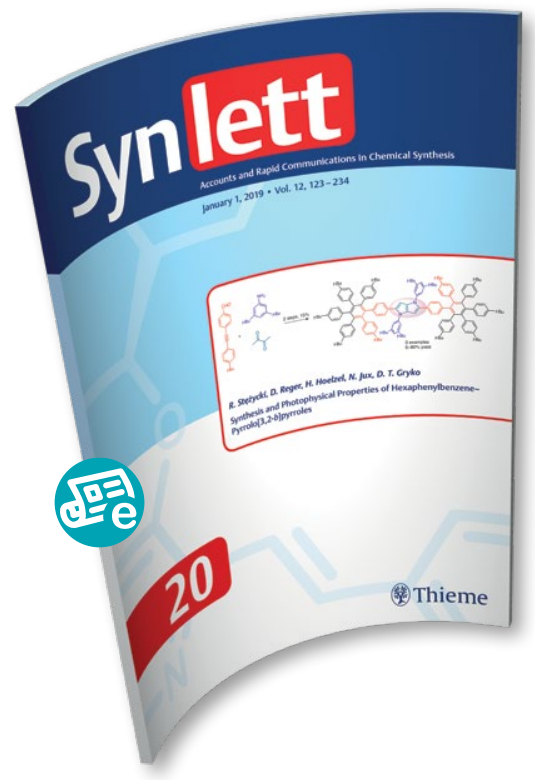

\section{SYNLETT}

\section{Accounts and Rapid Communications in Chemical Synthesis}

SYNLETT is an international journal reporting research results and trends in chemical synthesis in short personalized reviews and preliminary communications.

- International letter journal

- Impact Factor 2020: 2.454

- Publication of chemical primary data

- 20 issues per year

- Select Crowd Review available

- Dependable research results

- Experimental procedures

www.thieme-chemistry.com/synlett

Editor-in-Chief: $\quad$ Editors:

\section{B. List \\ A. Li}

Mülheim a. d. Ruhr, Shanghai, P.R. of China Germany

R. Martín
Tarragona, Spain

D. Nicewicz

Chapel Hill, USA

T. Rovis

New York, USA

Y. Uozumi

Okazaki, Japan

K. P. C. Vollhardt

Berkeley, USA

Crowd Review Editor:

M. van Gemmeren

Münster, Germany

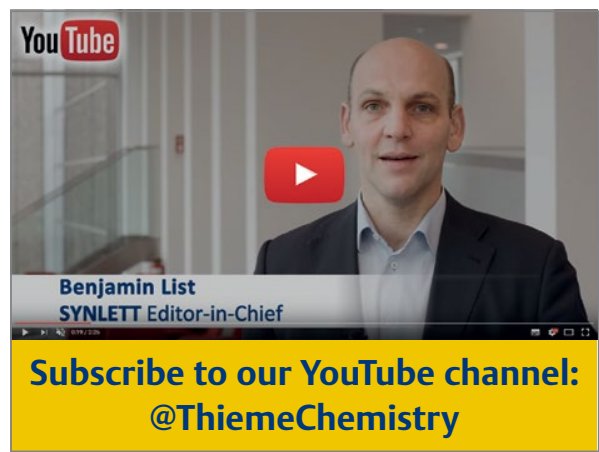

1 paper, $\mathbf{7 2}$ hours, 100 reviewers:

Select Crowd Review is an interactive and safe way to improve the quality and speed of publishing. A selection of 50-100 experts, who are exclusive members of the crowd, can comment on the manuscript anonymously via a secure web-interface.

\section{Learn more}

www.thieme-chemistry.com/crowdreview 


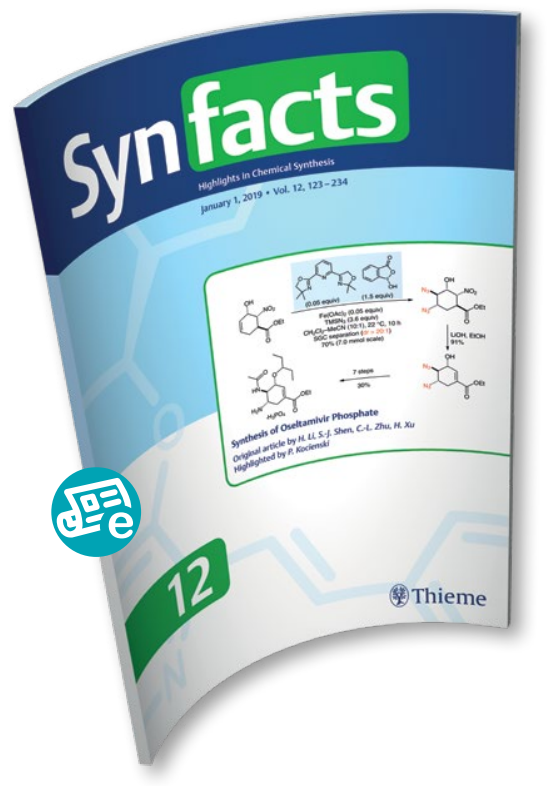

Editors:

E. M. Carreira

Zurich, Switzerland

P. J. Kocieński

Leeds, UK

M. Lautens

Toronto, Canada

B. List

Mülheim a. d. Ruhr,

Germany

Martin Oestreich

Berlin, Germany

M. A. Reed

Toronto, Canada

P. F. Richardson

San Diego, USA

T. M. Swager

Cambridge, USA

D. Trauner

New York, USA

Y. Uozumi

Okazaki, Japan

H. Yamamoto

Kasugai, Japan

\section{SYNFACTS}

\section{Highlights in Chemical Synthesis}

In SYNFACTS, current research results in chemical synthesis from the primary literature are evaluated, summarized and enriched with personal comments by experts in their fields on a monthly basis. The journal stimulates the reader's research and the development of exciting new ideas.

SYNFACTS covers the following categories:

- Synthesis of Natural Products and Potential Drugs

- Synthesis of Heterocycles

- Synthesis of Materials and Unnatural Products

- Metals in Synthesis

- Polymer-Supported Synthesis

- Organo- and Biocatalysis

- Chemistry in Medicine and Biology

- Peptide Chemistry

- Flow Chemistry

www.thieme-chemistry.com/synfacts

SYNFACT Classic

highlights seminal papers

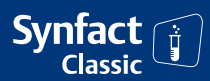
from the last decade that provided a landmark and paved the way for future breakthroughs in chemical synthesis.

\section{SYNFACT of the Month} highlights outstanding articles of the latest research results in chemical synthesis (available free of charge online). 


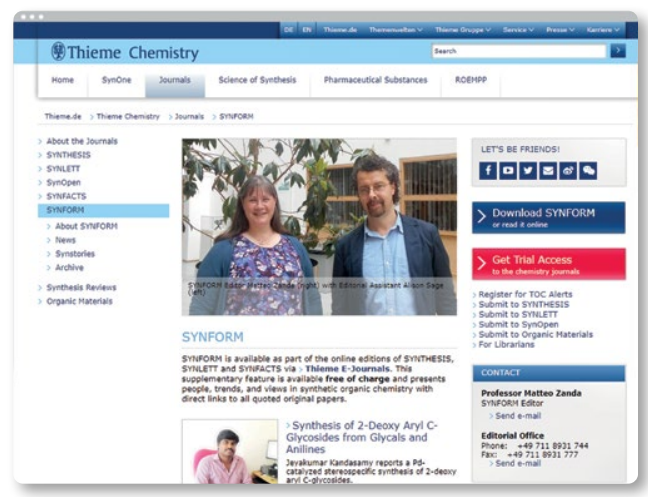

Editor:

M. Zanda

Milan, Italy

\section{SYNFORM}

\section{People, Trends and Views in Chemical Synthesis}

SYNFORM presents news from the synthetic chemistry community, including direct links to all quoted original papers, and is available free of charge.

It presents in a thought-provoking manner:

- New scientific advances in organic chemistry and related fields

- Facts and people from the world of chemical sciences

- Highlights from international chemistry conferences

- Development of important technological applications

- Biographies of researchers who gave important chemical reactions their name www.thieme-chemistry.com/synform

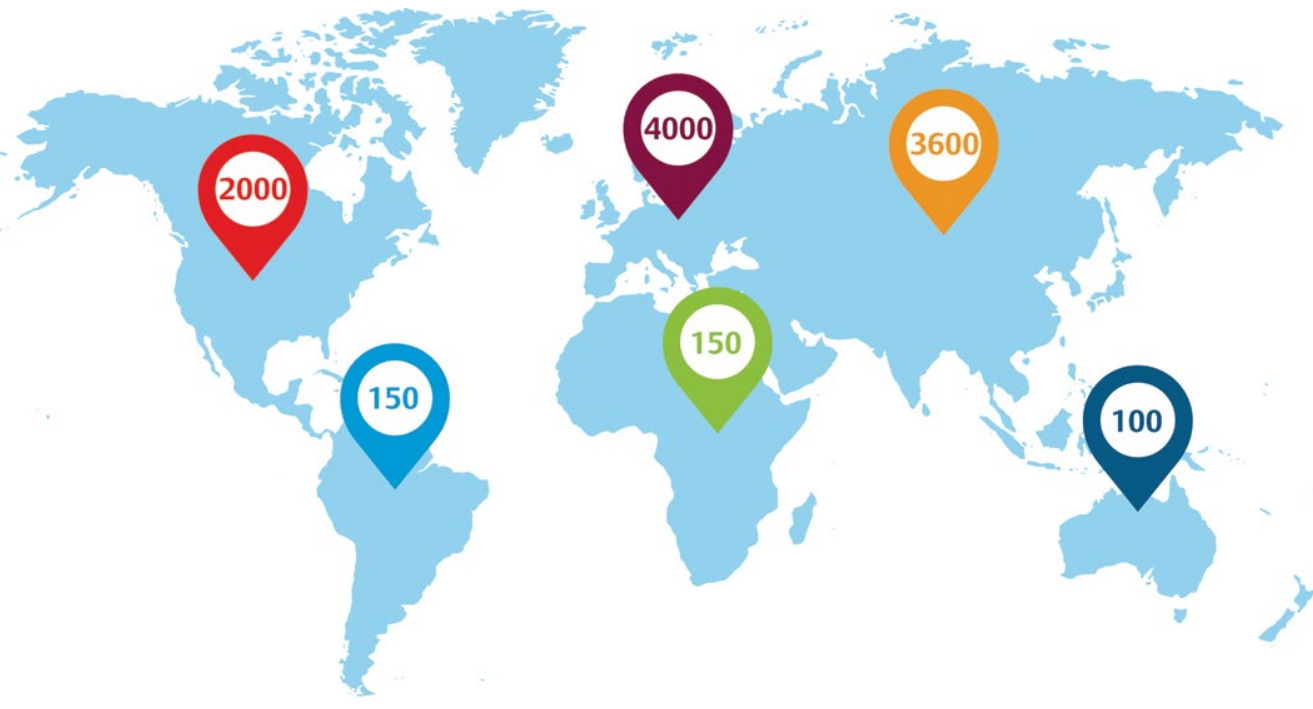




\section{Thieme Chemistry Prizes and Awards}
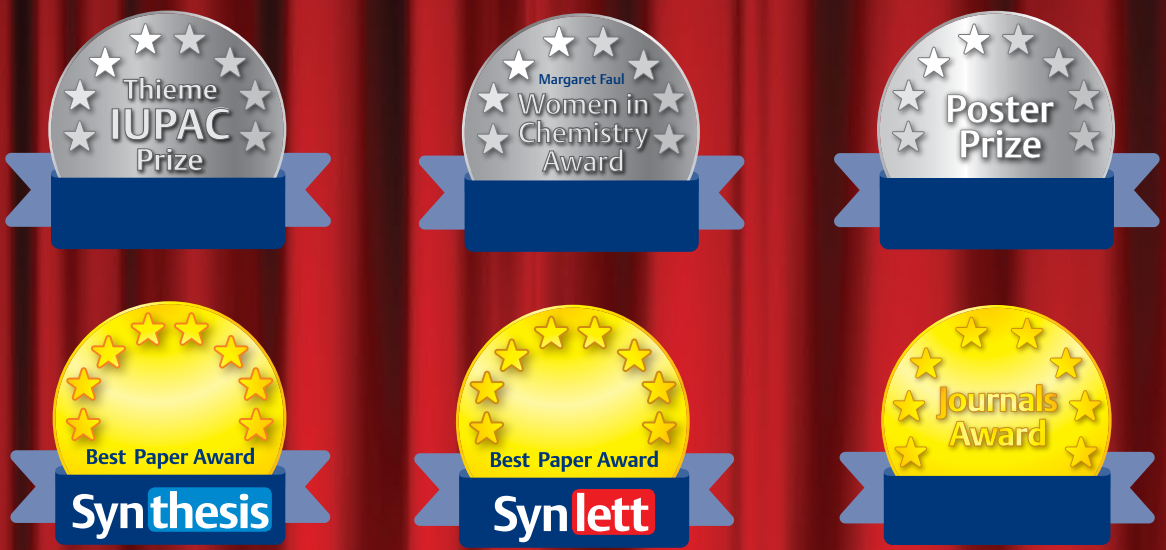

Thieme actively promotes scientific engagement and excellence in research with a comprehensive awards program. The prizes and awards strongly focus on young researchers, aiming to recognize early achievements and supporting their independent careers.

The Thieme-IUPAC Prize is awarded biennially to a scientist under 40 years of age whose research has had a major impact in synthetic organic chemistry.

The Women in Chemistry Award is awarded biennially to female chemists who have made outstanding contributions to research in organic chemistry.
The SYNTHESIS / SYNLETT Best Paper Awards honor the best original paper per year in each of the journals, considering their immediate impact on the field of chemical synthesis.

The Thieme Chemistry Journals Awards are annually given to up-and-coming researchers worldwide who are in the early stages of their independent academic career.

\section{Learn more: www.thieme-chemistry.com/awards}




\section{Planta Medica}

\section{Planta Medica}

Journal of Medicinal Plant and Natural Product Research

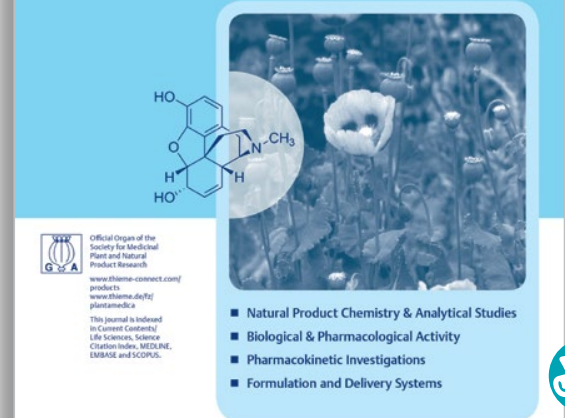

埢Thieme

\section{Drug Research}

\section{Drug Research}

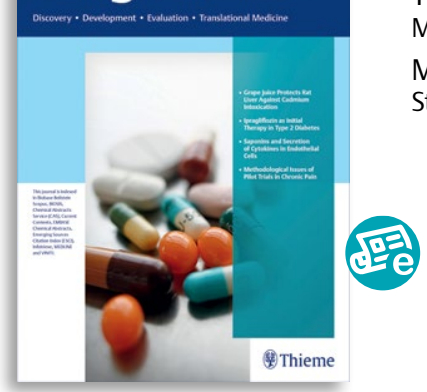

Drug Research is an international peer-reviewed journal presenting the latest research results related to novel and established drug molecules and the evaluation of new drug development.
Editors-in-Chief:

Oliver Kaysert

Dortmund, Germany

Robert Fürst

Frankfurt, Germany

Planta Medica is one of the leading international journals in the field of natural products including marine organisms, fungi as well as micro-organisms - and medicinal plants. Planta Medica accepts original research papers, reviews, minireviews and perspectives from researchers worldwide.

\section{Pharmaceutical Fronts}

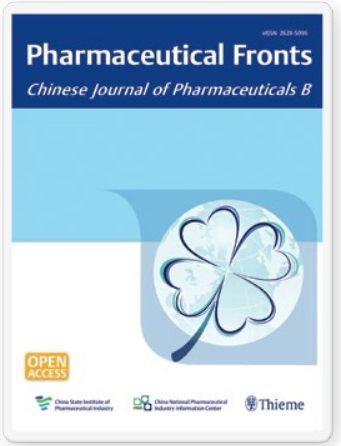

Editor-in-Chief:

Fen-Er Chen

Shanghai, China

Pharmaceutical Fronts is an international peer-reviewed journal focusing on the rapid and high-quality dissemination of the latest breakthroughs in pharmaceutical development across major scientific and engineering disciplines. It is an affiliated journal of the Chinese Journal of Pharmaceuticals. 


\section{Science of Synthesis}

Your expert guide to making molecules
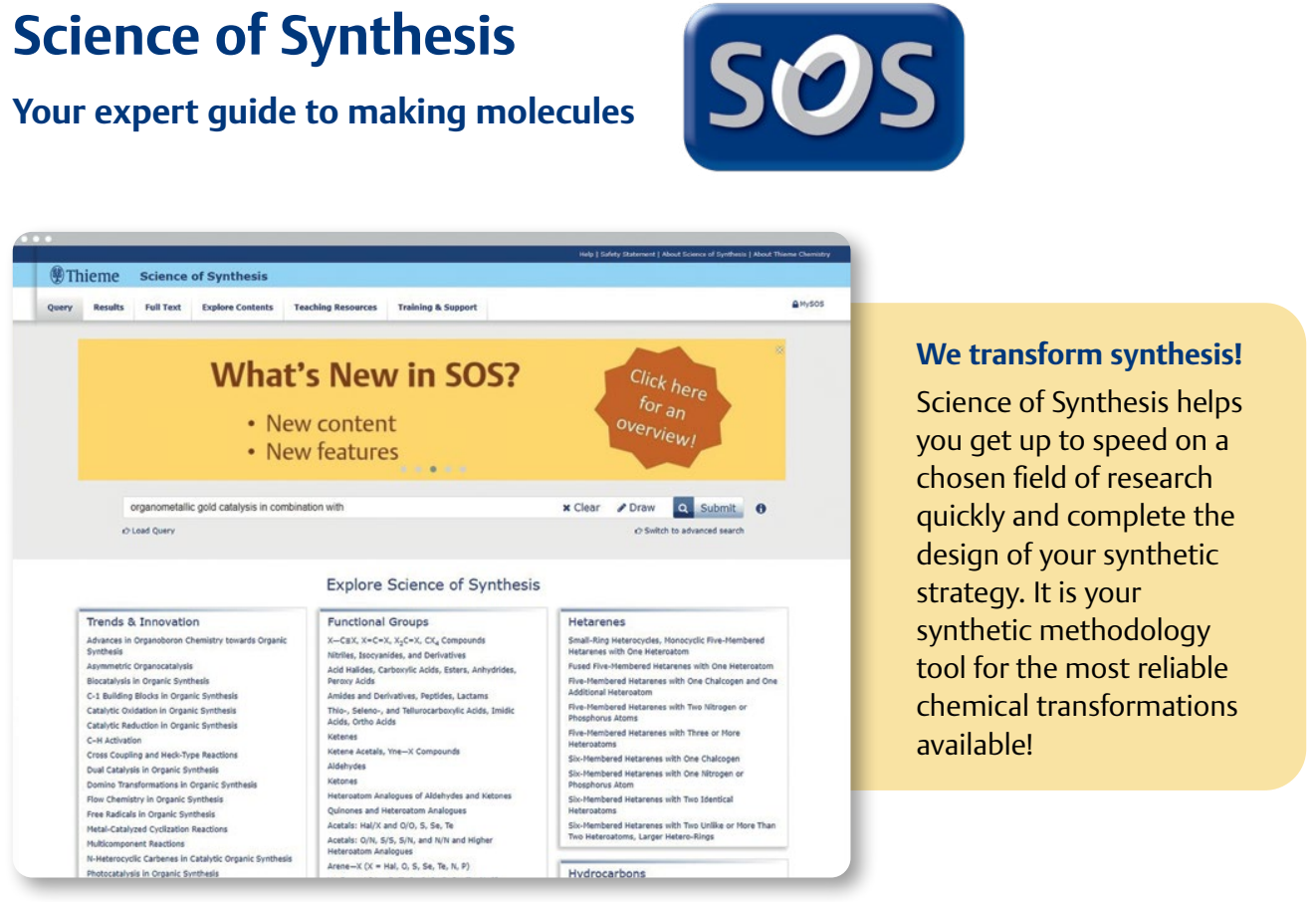

\section{What's new in Science of Synthesis?}

Among others, the following special topics and content updates have been included in previous years:

Reference Library:

- Electrochemistry in

Organic Synthesis

Volume Editor: Lutz Ackermann

- Click Chemistry

Volume Editor: Floris P. J. T. Rutjes

- Free Radicals: Fundamentals and Applications in Organic Synthesis Volume Editors: Louis Fensterbank and Cyril Ollivier

- Dual Catalysis in Organic Synthesis Volume Editor: Gary Molander

- Advances in Organoboron Chemistry towards Organic Synthesis

Volume Editor: Elena Fernández

Reference Library

Chapters as part of the Knowledge Updates series:

Organometallics

- Arylstannanes

- Chiral Scandium Complexes in Asymmetric Synthesis

- Stannoles and Germoles

Heterocycles

- Piperazines

- Pyrido[1,2-a]indoles and Analogues

- Azaborines

- 1,4-Dioxanes

- Purines
Functional Groups and Other Topics

- Allylsilanes

- Synthesis of Amines by Rearrangement

- Synthesis of Amides by Transamidation and Amidation of Activated Amides and Esters

- Alkane Metathesis

- Biocatalytic Oxidation of Alcohols

- Cyclobutanes

- 1,2-Diimines and 1,3-Diimines 


\section{Essential for synthetic organic chemists}

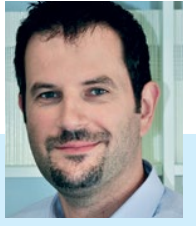

To me, the true value of

Science of Synthesis is its systematic approach to reprocess the state-of-the-art for any functional group. When I quickly need a competent overview of the chemistry of this or that class of compounds, Science of Synthesis is my immediate choice. Conventional review articles do usually not provide this information."

Martin Oestreich TU Berlin, Germany

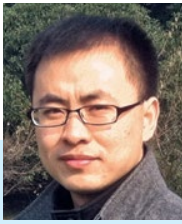

I strongly recommend Science of Synthesis

because it not only provides an effective method to find information for your research, but also is a very useful resource to organic chemists and graduate students.

From SOS, you can easily find the history and development of each type of reaction. [...] Try it, I really believe you will find something different here."

Shuanhu Gao East China Normal University, Shanghai, P.R. of China

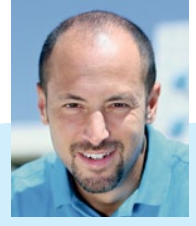

Science of Synthesis is an indispensable tome of chemical information organized in an intuitive and logical way. It contains information on nearly every aspect of chemical reactivity and, for me, is the "go-to" resource for rapidly learning about a new area. I use it regularly in preparation for classes and for consulting visits - it simply gives me the information I need far more easily than any search engine is capable of - and very often contains references and insight that cannot be found anywhere else."

Phil Baran

Scripps Research Institute, La Jolla, CA, USA

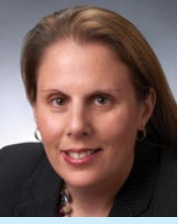

Science of Synthesis has done a nice job of establishing a useful resource for synthetic chemists including some important contributions from my industry colleagues. It's important to remember that industry has considerable expertise here, and this provides a powerful forum for scientific exchange.

Rebecca Ruck, Merck Sharp \& Dohme Corp., NJ, USA 


\section{Science of Synthesis}

\section{Electronic Edition}

Science of Synthesis (SoS) is your synthetic information tool for the most reliable chemical transformations available. It is particularly useful if you are looking for a reliable and condensed overview of a specific topic in the field of organic and organometallic transformations, whether that be the synthesis of a particular heterocycle or the catalytic applications of certain organometallic complexes.

SoS is the only resource providing full-text reviews of organic and organometallic transformations, experimental procedures as well as unique insights into the scope and limitations of synthetic methods.

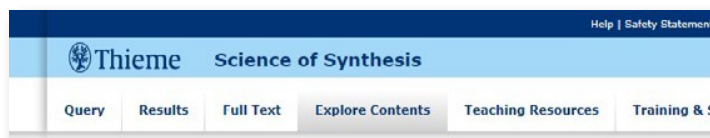

Discover reliable transformations! The "Explore Contents" tab presents a uniquely-organized classification of organic and organometallic transformations, and offers a systematic approach to putting synthetic methods in context.

\section{Editor- in-Chief}

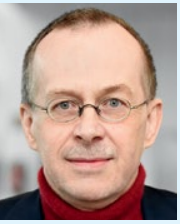

Alois Füstner Max-Planck-Institut für Kohlenforschung Germany

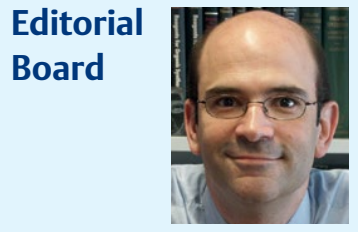

Erick M. Carreira ETH Zurich Switzerland

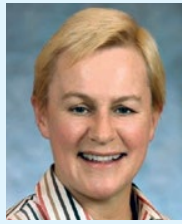

Margaret Faul AMGEN Inc. CA, USA

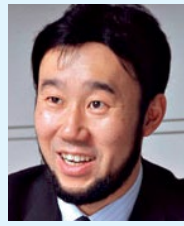

Shu Kobayashi University of Tokyo Japan 


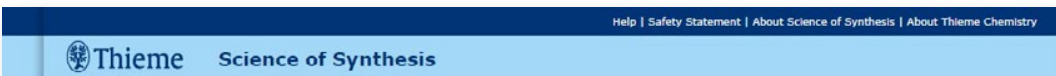

(2) Download PDF

aysos

NAVIGATION

0 Hits

Previous / Next

\section{SOS SOScence of}

Knowledge Updates 2021/3

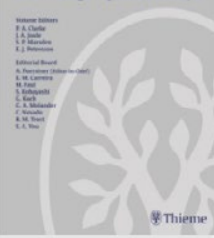

10.24 Pyrido[1,2-a]indoles and Azapyrido[1,2-a]indoles

DOI: $10.1055 /$ S0S SD 110.01869

Harris, P. A., Science of Synthesis Knowledge Updates, (2021) 3, 1.

\section{General Introduction}

The synthesis and chemistry of pyrido[1,2-a]indoles 1 (Scheme 1) are reviewed as a subclass in Section 10.24.1. Since the published chemistry around the core pyrido[1,2-a]indole tricycle is limited, related systems with benzofused rinas at the pyridine rina, namely indolo[ 1,2 -a $]$ quinolines 2 , indolo[ $[1,2-b]$ isoquinolines 3 , indolo $[2,1$ a] lisoquinolines 4 , and indolo[1,2-flphenanthridines 5 , are covered in this subclass. Since they are grouped together, to avoid confusion, the numbering system used in the section titles to described the bonds formed will follow that for the core pyrido[1,2 - a indole (1) tricycle, as illustrated in Scheme 1.

Scheme 1 pyrido[1,2-a]indole and Related Benzo-Fused Ring Systems
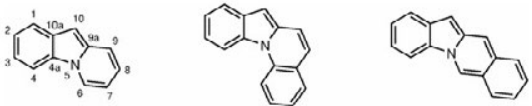

1 pyridol 1,2 -aindole

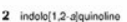

3 indelo/1,2 biscoginoline
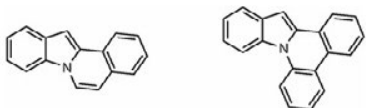

5 indolot 1.2-fphternanturidi

4 indolo[2.1-alisoquinaline

In addition, azapyrido $[1,2-a]$ indoles, namely pyrimido $[1,2$-a]indoles 6 , pyrimido $[1,6$-a $]$ indoles 7 , pyrazino $[1,2$ a] indoles 8, and pyridazino[1,6-a]lindoles 9 (Scheme 2) are reviewed as separate subclasses in Sections 10.24.210.24 .5 .

Scheme 2 Azapyrido[ 1,2 a ]indolo Ring Systems

\section{Get a comprehensive overview!}

The full-text reviews include in-depth discussion of reliable organic transformations. The chapters were contributed by over 2,000 experts in synthetic chemistry.

\section{Sign up for a free trial: www.thieme.de/sos-trial}

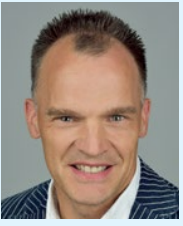

Guido Koch Amphilix Switzerland

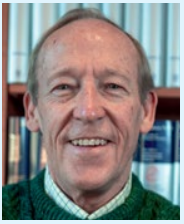

Gary A. Molander University of Pennsylvania PA, USA

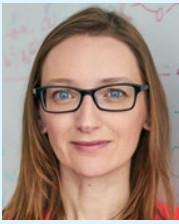

Cristina Nevado University of Zurich Switzerland

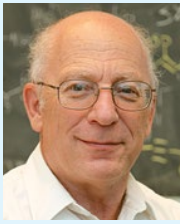

Barry M. Trost Stanford University CA, USA

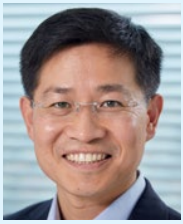

Shu-Li You Shanghai Institute of Organic Chemistry (SIOC) P.R. of China 


\title{
Pharmaceutical Substances
}

\section{Syntheses | Patents | Applications}

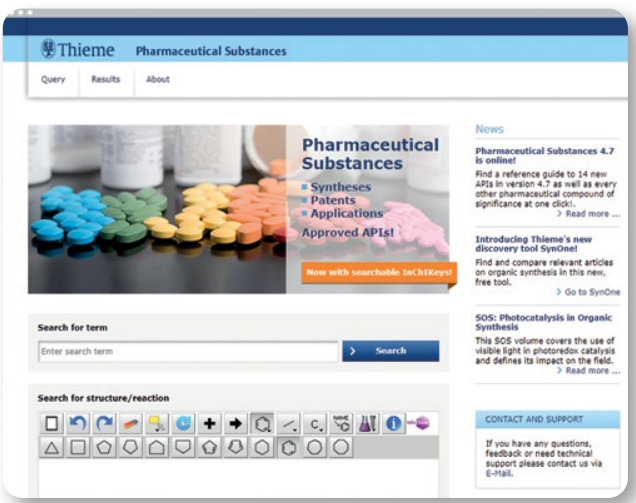

Pharmaceutical Substances is a one-stop online source of information relating to the industrial synthesis and commercial applications of every licensed drug of significance. It provides ready access to syntheses, patents, and applications for more than $\mathbf{2 , 7 0 0}$ active pharmaceutical ingredients (APIs).

Profs Axel Kleemann, Jürgen Engel, Bernhard Kutscher and Dietmar Reichert present highly evaluated information collected from all the relevant literature and commercial patent data.

The information is also available on STN.

\author{
A. Kleemann \\ Hanau, Germany \\ B. Kutscher \\ Maintal, Germany | BK HC Consulting \\ D. Reichert \\ Hanau, Germany | Evonik Industries AG \\ and formerly: \\ J. Engel \\ Saarbrücken, Germany | ElexoPharm GmbH
}

The print version provides a compendium of over 1,300 of the most significant pharmaceutical compounds that are of interest to the chemical and pharmaceutical industries.

\author{
A. Kleemann, J. Engel, B. Kutscher, D. Reichert: \\ Pharmaceutical Substances \\ 5th edition • 1800 pp. $\bullet 2009$ \\ ISBN: 978-3-13-558405-8 \\ EAAA $€ 607,99 \cdot$ Am US\$ 849,99
}


Factual data

(Chemical name and formula,

INN standard, trivial names, synonyms, CAS registry number and ATC codes, InChl keys, medical applications and therapeutic category...)

Access to other drugs of this substance class

Synthetic route(s) used for industrial large-scale production

Intermediates and their factual data

Trade names and vendors for the most important markets

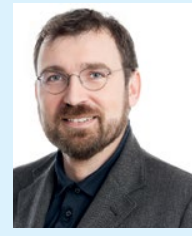

I love Kleemann/Engel [Pharmaceutical Substances] because it helps me prepare for classes, in particular on synthetic design. I don't only cover natural products but also multistep drug syntheses in these courses. It's also very useful for introductory classes in organic chemistry to illustrate, for instance, Friedel-Crafts reactions or Mannich reactions with concrete and important examples. Especially the premeds love it when I show an application in a drug synthesis."

Dirk Trauner New York University, New York, USA 


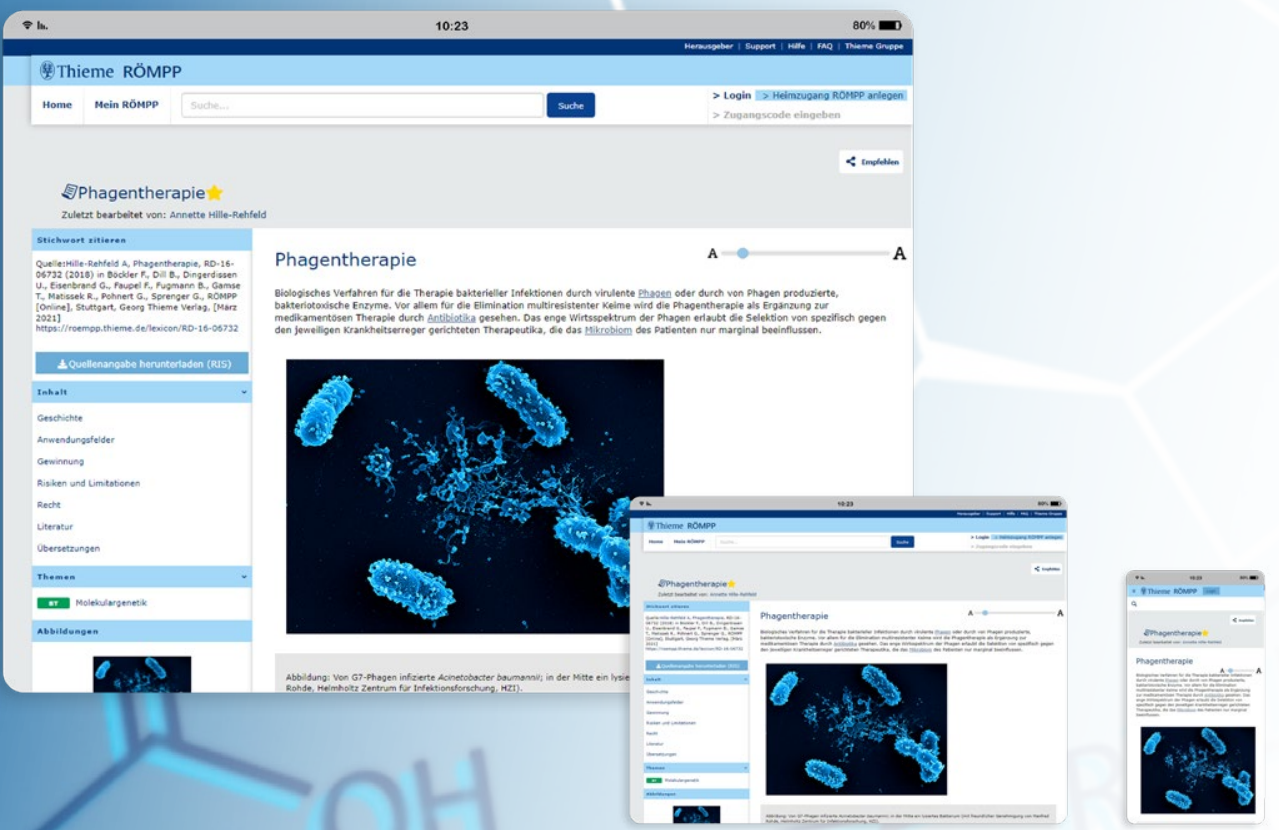

Herausgeber

\section{Chemie}

B. Dill

F. Böckler, Tübingen

Biotechnologie und Gentechnik

G. Sprenger, Stuttgart

S. Schmidt, Groningen

Lebensmittelchemie

G. Eisenbrand, Kaiserslautern

R. Matissek, Köln

Naturstoffe

B. Fugmann, Leverkusen

G. Pohnert, Jena

Materialwissenschaft und

Werkstofftechnik

F. Faupel, Kiel

Umwelt- und Verfahrenstechnologie
A. Rühling, Darmstadt
T. Gamse, Graz

\section{RÖMPP}

\section{Schnell und einfach zum gesicherten Wissen der Chemie.}

Der RÖMPP ist die renommierteste deutschsprachige Online-Enzyklopädie rund um das Themenfeld Chemie. Nahezu jede deutsche Universität, große Pharma-Unternehmen, Umweltforscher, Patentanwälte und das

BKA - sie alle vertrauen RÖMPP!

\section{Die Zuverlässigkeit der Inhalte macht den Unterschied.}

Alle Inhalte des RÖMPP werden von erfahrenen Experten erstellt und geprüft. Ein Team ausgewählter Herausgeber, Redakteure und 100 Autoren sorgt dafür, die hohen Anforderungen der Fachwelt zu erfüllen. 


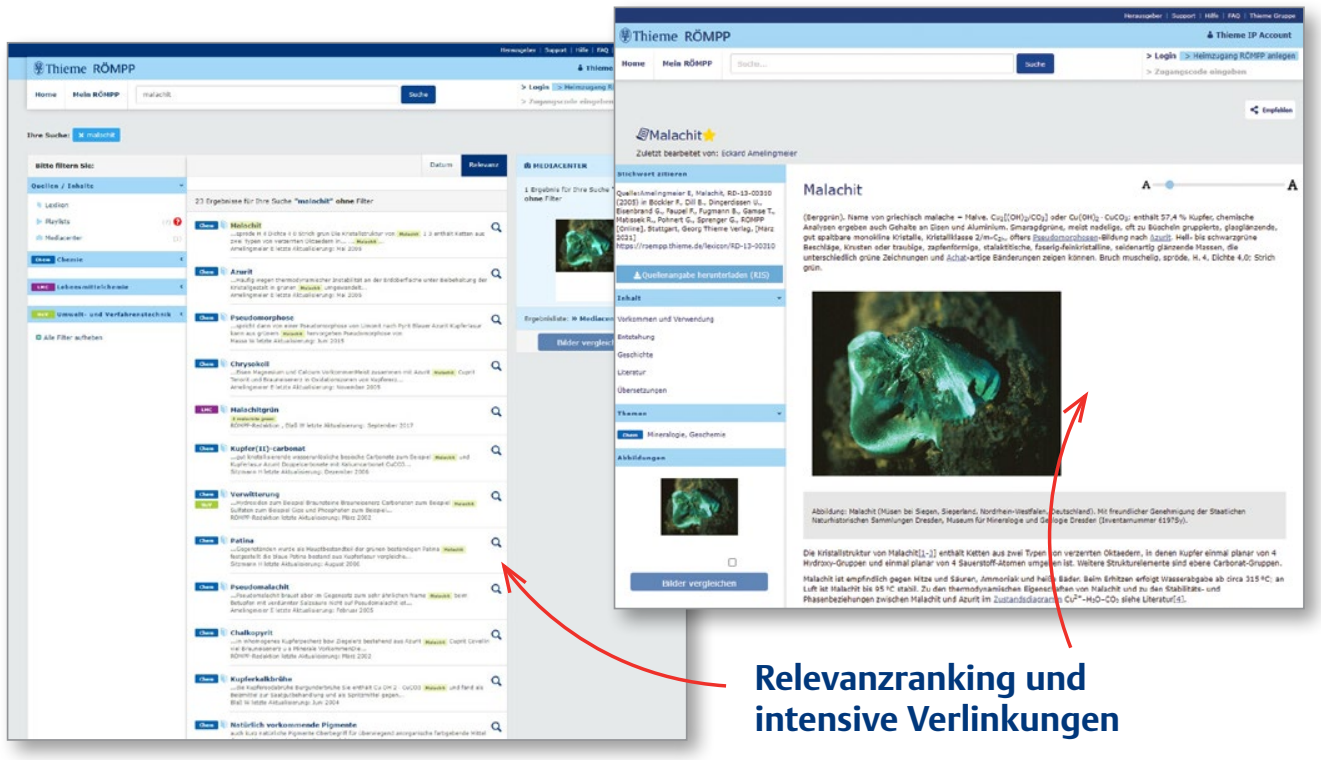

Der RÖMPP umfasst mehr als 64.500 Stichwörter, 295.000 Querverweise, 46.000 Weblinks sowie 24.000 Strukturformeln und Grafiken aus folgenden Fachgebieten:

- Chemie

- Biotechnologie und Gentechnik

- Materialwissenschaft und Werkstofftechnik

- Lebensmittelchemie

- Naturstoffe

- Umwelt- und Verfahrenstechnologie

\section{Warum RÖMPP?}

- Hohe Qualität und Zuverlässigkeit der Inhalte durch Fachexperten gesichert

- Zahlreiche Verlinkungen innerhalb des RÖMPP sowie Literaturangaben und weiterführende, externe Links

- Klar gestaltete Benutzeroberfläche mit Relevanz-Ranking der Suchfunktion

- Mit allen Endgeräten rund um die Uhr erreichbar

- Persönliche Ansprechpartner bei der Redaktion und den Autoren für Ihre Rückfragen

- Kontinuierliche Updates

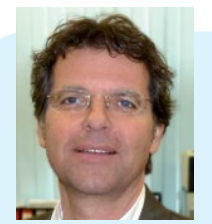

„Das Chemiestudium erfährt über die neuen Masterstudiengänge eine starke Individualisierung mit Anleihen an benachbarte Disziplinen der Bio- und Materialwissenschaften. Der schnelle Zugriff auf aktuelle und fachlich abgesicherte Einstiegsinformationen ist für Studierende essentiell. Die große Welt des RÖMPP dient als erste Leitschnur für tiefer schürfende Ausflüge in diese Grenzbereiche. Er spiegelt in idealer Weise die universitäre Moderne und begeistert durch „kinderleichte“ Bedienung.“

Andreas Kirschning Leibniz Universität, Hannover, Germany

\section{Jetzt kostenlos testen: thieme.de/roempp-trial}




\title{
Spectroscopic Methods in Organic Chemistry
}

Hesse - Meier - Zeeh

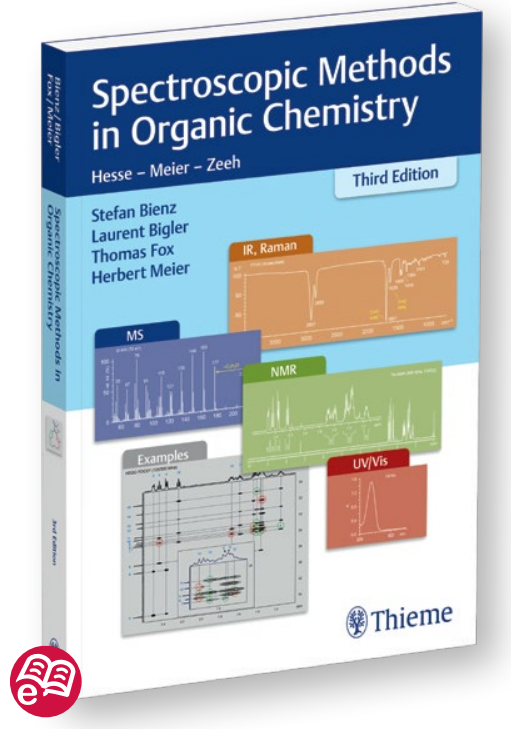

This reference work provides you with essential knowledge for the application of modern spectroscopic methods in organic chemistry. It has been a standard reference for decades and is compulsory reading for every organic chemistry student!

The following methods are explained based on typical practical examples, theoretical aspects, and applications:

- UV/Vis Spectroscopy

- Infrared and Raman Spectroscopy

- Nuclear Magnetic Resonance Spectroscopy

- Mass Spectrometry

Bienz et al.: Spectroscopic Methods in Organic Chemistry

3rd edition $\bullet 1184$ pp. $\bullet 2021$

ISBN 978-3-13-243408-0

EAAA $€ 89,99 \cdot A m$ US\$ 99.99

\section{Protecting Groups}

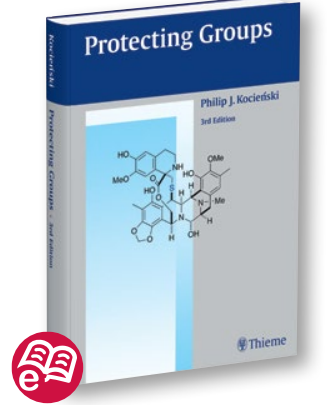

The didactic presentation of the material makes this book an essential bench-top tool for students as well as specialists involved in organic chemistry in academia and industry.

\section{Synthetic Methods}

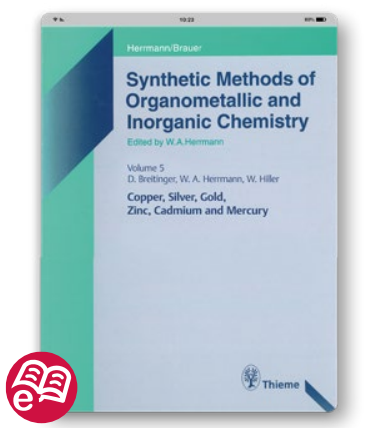

The series includes detailed and reliable experimental procedures for the preparation of common but important starting compounds, organized according to the periodic table.

\author{
Hermann et al.: Synthetic Methods of \\ Organometallic and Inorganic Chemistry \\ 2,548 pp. in total • published from 1996 to 2002 \\ Volume 1 - 10 \\ each Volume \\ EAAA $€$ 109.99-139.99 • Am US\$ 139.99-179.99
}




\section{Spektroskopische Methoden}

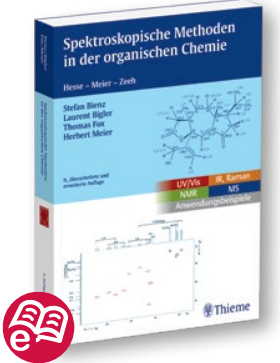

Dieses Standardwerk vermittelt relevante Kenntnisse für die Anwendung spektroskopischerMethoden in der Organik. Einführende Grundlagentexte erläutern die Theorie, anschauliche Beispiele (inkl. kostenloser Übungsbeispiele) die Umsetzung in der Praxis.

\section{Bienz et al.: Spektroskopische Methoden in der} organischen Chemie

9. Auflage • 456 S. • 2016

ISBN: 978-3-13-576109-1

EUR [D] 91,99・EUR [A] 94,60・sFr 103,00

\section{Efficiently Studying Organic Chemistry}

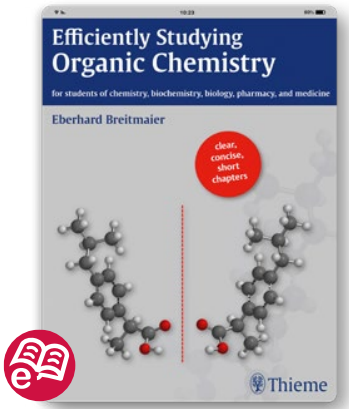

This e-book for bachelor and master students facilitates effective learning and is renowned for the quality of its content presented in 81 short chapters.

\section{Chemie}

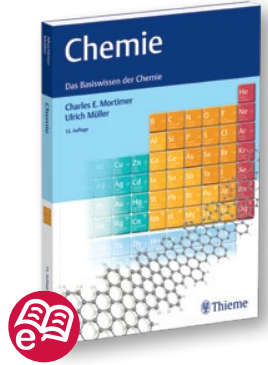

Der Mortimer ist das meistverkaufte Lehrbuch seiner Art, denn er macht Chemie anschaulich. Er bietet die sichere Basis für Chemiestudierende und alles Prüfungsrelevante für Studierende der Natur- und Ingenieurwissenschaften. Das Mortimer-Versprechen: Chemie wird endlich leicht verständlich.

\section{Mortimer, Müller: Chemie}

13. aktualisierte Auflage • 720 S. • 2019

ISBN: 978-3-13-242274-2

EUR [D] 71,99・EUR [A] 74,10・sFr 80,00

\section{Organische Chemie}

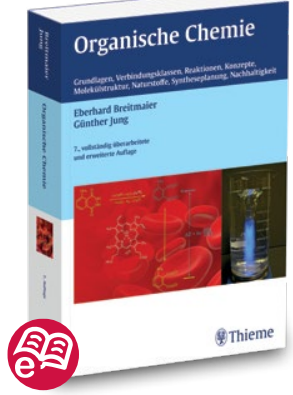

Das Lehrbuch umfasst relevante Themen der organischen Chemie anschaulich, kompakt und prüfungsnah und wurde um die Kapitel „Biosynthesen“, „Syntheseplanung“, „Nachhaltigkeit und nachwachsende Rohstoffe" erweitert. 


\section{Would you like to learn more?}

Please contact us!

Thieme Chemistry

Phone +49711 89310

customerservice@thieme.de

Join our Author Community on Social Media!

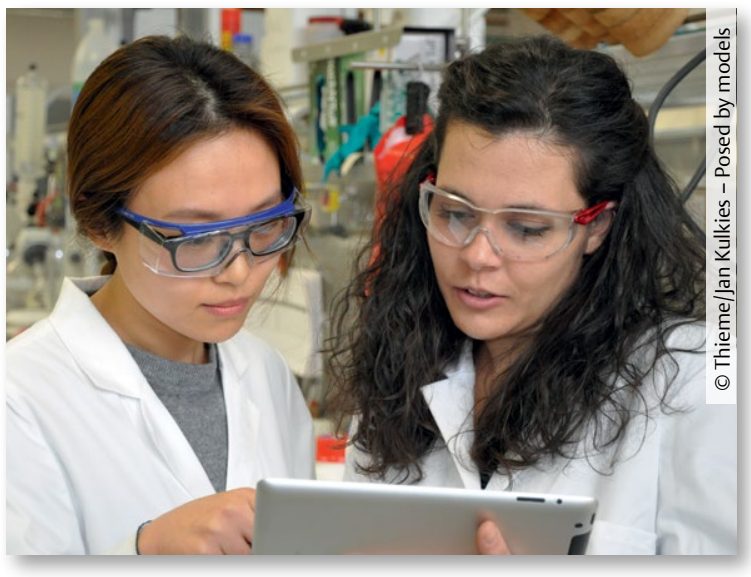

Use these ways to order:

\section{Electronic Products}

The Americas

Thieme Institutional Sales

Phone +1 2125844695

esales@thieme.com

Europe, Africa, Asia and

Australia (except India)

Thieme Institutional Sales

Phone +497118931407

eproducts@thieme.de

India

Thieme Medical and Scientific

Publishers Private Ltd.

Phone +91 1204556600

eproducts@thieme.in

\section{Print Products}

The Americas (except Brazil)

Thieme Publishers New York

Phone +1 2127600888

Toll free (USA): +18007823488

customerservice@thieme.com

DACh (Germany, Austria, Switzerland)

Georg Thieme Verlag KG

Phone +497118931900

kundenservice@thieme.de

Europe, Africa, Asia and Australia

(except DACh and India)

Thieme Publishers Stuttgart

Phone +497118931421

customerservice@thieme.de
Brazil

Publicações LTDA

Phone +55 2137363631

Thieme.Brazil@thieme.com

India

Thieme Medical and Scientific

Publishers Private Ltd.

Phone +91 1204556600

customerservice@thieme.in

\section{Find more information: www.thieme-chemistry.com}

